\title{
The Cold War on the Ground: Reflections from Jinmen
}

\section{MICHAEL SZONYI}

$\mathrm{T}$ HE PURPOSE OF THIS JAS roundtable is to reflect on the Cold War in Asia. Even to frame the issue in such terms is to confront the "formidable semantic contradiction that is inherent in the idea" of the Cold War (Kwon 2010, 7). For the very notion of the Cold War-as a "long peace" in which bipolar tensions did not lead to hot war-sits uneasily with the reality that in Asia bipolar tensions were imbricated in horrific conflicts that left millions of human casualties. On the other hand, to use the term "Cold War" simply as a label for a historical period, or "epoch" in Alfred McCoy's terms, is to invite imprecision. Moreover, even as a label for a historical period, the term still effaces the experience of much of the world, since the end date of the period is defined by the experience of Europe and the superpowers.

Heonik Kwon responds to this dilemma by calling for the "decomposition of the cold war," by which he means, among other things, treating Cold War history as an anthropological as well as a historical problem, "both in the sense that an understanding of how the peripheral others experienced and recount the history of the cold war is central to putting into perspective the way in which the exemplary center conceptualizes the nature of this history and also in the sense that struggles between the image of the whole and representation of the parts are critical to the understanding of the global cold war" (Kwon 2010, 7). While not all of them would accept Kwon's language, a growing number of historians are taking up this very challenge, seeking to understand the specific ways that bipolar rivalry affected the societies and peoples of Asia and vice versa. Such efforts are part of two larger trends in the historiography of the Cold War. The first is the effort to situate the Cold War in relation to other long-term international and global transformations. The second is the effort to enlarge the field of Cold War history from the realms of diplomacy and security into areas such as society, culture, science and technology, and even environmental history.

McCoy's contribution to the roundtable belongs to the first approach. He argues that the "real story" of the period is not the Cold War so much as decolonization and the emergence of new expressions of the pursuit for global hegemony. McCoy's perspective is basically realist, but he points out that US support for nondemocratic regimes undermined its own legitimacy claims. Military bases thus "reveal the reality that their rhetoric obscures." Michael Bodden's paper combines the first and second approach, but he

Michael Szonyi (szonyi@fas.harvard.edu) is Professor of Chinese History in the Department of East Asian Languages and Civilizations, and Director of the Fairbank Center for Chinese Studies at Harvard University.

${ }^{1}$ To this point, I would add Grandin's (2004) observation that US interventionism was not simply the dark side of a morally good global strategy to defend freedom against the evils of communism, 
too focuses on the first. The key difference is that he identifies a different "real story"domestic political disputes in the late twentieth century may have been linked to superpower intervention, but were fundamentally about competing views of how the peoples and nations of Asia should define and attain modernity.

Like McCoy, I think that military bases are a useful window onto important questions. Like Bodden, I am interested in how the peculiar interaction between the local and the global in this period was experienced. In this short essay, I use some examples drawn from my previous research on the island base of Jinmen (also known as Quemoy) in the Taiwan Strait to pursue the second approach, that is, considering what the Cold War meant in domains of human experience outside diplomacy and security. ${ }^{2}$ Jinmen differs somewhat from the bases of McCoy's paper. It was not created in support of American military power or political hegemony; it was not a site of extraterritoriality; and the soldiers stationed there were citizens of the Republic of China, not its superpower ally. Americans only ever made up a minuscule proportion of the troops and advisers stationed there. But the logics of the military base certainly apply to Jinmen. As scholars like Catherine Lutz (2001) have shown, military bases can be highly productive sites for social and cultural historians. They are places where supposed boundaries between civil and military blur, thereby revealing their fundamental arbitrariness. It is on and around military bases that people live political tension, both hot and cold, as part of everyday lives.

The island archipelago of Jinmen, a few miles from the coast of the Chinese mainland, was the site of an unexpected victory by the forces of Chiang Kai-shek's Republic of China army as they retreated to Taiwan in the waning months of the Chinese Civil War. Holding Jinmen against the larger forces of the People's Liberation Army was an enormous symbolic victory. To protect it from an expected subsequent assault and, at least in the early years, so that it could serve as a staging point for a planned reconquest of the mainland, Chiang stationed a huge garrison on the island. The United States sought to exclude the island from its mutual defense arrangements with Taiwan. In a bid to outsmart his superpower ally, Chiang Kai-shek expanded the garrison with a significant proportion of his total armed forces. This made it possible for him to argue that defense of Jinmen was critical to the defense of Taiwan-which would be all but defenseless if Jinmen ever fell—and so effectively brought it under the American security umbrella.

In the next decade, the island twice came to world attention, during the two Taiwan Strait Crises of 1954-55 and 1958, when it was devastated by fierce artillery barrages by the People's Liberation Army (PLA) and the United States considered military intervention in its defense. These events are well known, though still debated; less well known is that the island remained home to a civilian population. Over a period of forty years, much of Jinmen was taken over by the Republic of China (ROC) military; besides the loss of their land, residents also suffered from a host of other restrictions, injuries, and inconveniences. Perhaps most bizarrely, from 1958 to 1978 the island was subject to bombings on

for it also implicates the United States in the legitimization of terror and violence as political tactics.

${ }^{2}$ The body of this paper summarizes material in Szonyi (2008, 2011, 2013). 
every alternate day. Since the early 1990s, improving relations between Taiwan and mainland China have led to demilitarization of the island. As with so many other military bases around the world, the withdrawal of troops brought new challenges, throwing the local civilian economy into crisis.

The effect of the military presence on Jinmen was the militarization of the civilian society. By militarization, I do not mean the deliberate process by which states enhance their capacity to make or defend against war, but rather, following Enloe (2000, 291), "the step-by-step process by which something becomes controlled by, dependent on, or derives its value from the military as an institution or militaristic criteria." On Jinmen, militarization in this broader sense meant the mobilization of the populace to support the ROC military and the subordination of their interests to military concerns. The list of things that became militarized on Jinmen is almost endless. I will mention just three: rats' tails, basketballs, and the lives of women.

Rats' tails on Jinmen were first militarized because of the perceived danger of plague. With a significant proportion of the entire ROC army stationed on the island, an outbreak of plague on Jinmen might threaten not only the fighting capacity of the Jinmen garrison itself but also the defense of Taiwan. In the early 1950s, official discussion of plague conceived of it as a problem demanding technical solutions: inoculation, quarantine, and eradication of carriers. But the issue soon came to be generally understood as a problem of civilian backwardness and poor hygiene. (Probably the vast tunnel complexes built by the army and stored with emergency grain supplies had as much if not more to do with the matter.) By 1954, the need to eradicate rats to prevent plague had been converted into a problem of mass mobilization. Civilian households were required to meet a rat-killing quota that eventually was set at one rat per person per month. Compliance was ensured by requiring households to hand in the tails of the dead rats. In the second quarter of 1954, civilians turned in over 24,000 tails. ${ }^{3}$ While the consequences of plague continued to be seen in military terms, the cause of transmission-the prevalence of rats-now came to be understood as a problem of the backwardness of the civilian populace. Villagers who did not meet their quota were punished with forced labor. Rats' tails thus became imbued with considerable significance, tied to civilian discipline and hygienic modernity, and the need for constant preparedness to face a threatening foe.

Basketballs were militarized because, out of fears of defection and espionage, all objects that could be used as flotation devices were strictly regulated. These fears may have been overblown, but at least one celebrated defector, Justin Lin (Lin Yifu) - later to become chief economist of the World Bank-is rumored to have swum the narrow but treacherous waters separating Jinmen from the mainland with the help of a raft supported by basketballs. Village officials kept meticulous records of all the basketballs and inner tubes; registration booklets make up a considerable proportion of the surviving village archives.

Women's lives were militarized in multiple and contested ways. The idea that soldiers have sexual needs that must be met in order to keep them in fighting trim, and that prostitutes should meet those needs in order to protect civilian women, gave rise to a network

${ }^{3}$ Guofangbu and Jinmen xianzhengfu (1985) provides annual tallies for rats' tails submitted. The highest number is 226,000, submitted in 1973. 
of army-run brothels, known colloquially as 831. Women were brought from Taiwan to serve as prostitutes in the brothels, a product of these assumptions about militarized forms of masculinity (see Enloe 2000; Tanaka 2002, chap. 6). This is a dramatic example. But the lives of ordinary civilian women were also militarized by the massive troop presence after 1949, which disrupted the gender ratio, and hence the marriage market. In response to the large numbers of excess men on the market, local families tried to obtain brides for their sons by arranging marriages before their neighbors' daughters entered the marriage market. The result was that the age of marriage for girls fell dramatically. Brideprice, not traditionally associated with marriage in Jinmen, rose dramatically to reflect the increased value of women on the market. Young women in Jinmen were responsible, like their male counterparts, for serving in the island-wide compulsory militia. Unlike men, they served only until the time of their marriage, on the assumption that thereafter their time would be taken up with domestic duties. Militarization on Jinmen was a gendered phenomenon.

Militarization is not uniquely characteristic of the Cold War; it can occur in any society. But the contours of militarization on Jinmen were shaped by the chronology of the Cold War. I call this linkage "geopoliticization." By geopoliticization, I mean not simply the military significance of the island to global geopolitics or how the island was directly affected by global issues and forces. Rather, I use geopoliticization to describe how regional and global tension affected different aspects of human experience and social relations. On Jinmen, geopolitical conflict should be seen in terms of the interaction between multiple power regimes operating in overlapping fields, from the high-level diplomacy in Washington and Beijing to local village politics. I illustrate the notion of geopoliticization below by showing how the human experience of militarization on Jinmen was conditioned by geopolitical factors.

In 1958, the PLA launched a devastating attack on both military and civilian populations. Mao's reasons for launching the 1958 attack are still debated, but the larger geopolitical context figures in most explanations. Mao may have wished to signal his disapproval of US-ROC military cooperation, or challenge what he saw as US aggression in Iraq and Lebanon, or send a message to the Soviet Union warning that China would not acquiesce in Soviet revisionism. Even if, as some scholars have speculated, Mao's attentions were focused domestically, hoping to ratchet up external tension in order to mobilize the people behind the Great Leap Forward, the Leap itself both was shaped by and contributed to Sino-Soviet tensions. So, one way or another, the attack on Jinmen in 1958 was driven by Mao's efforts to respond to and to shape superpower rivalry.

Besides the damage in lost lives and destroyed homes, the 1958 Taiwan Straits Crises led to a host of changes for civilians. Civilian labor was requisitioned to provide support for the military even more than in the previous decade. The crisis reconfigured families, with children and youth evacuated to Taiwan. It reshaped the island's geography, with those parts of the island less exposed to mainland artillery guns developing at the expense of places more exposed. It affected even the schedules of everyday life for civilians, who for decades afterwards were forced to spend every alternate night in the bomb shelters that were built in every village. There was, in other words, a link between the global concerns of the People's Republic of China (PRC) at the highest level and the sleeping habits of Jinmen residents. This is geopoliticization. 
The 1958 attack is also interesting as a demonstration of how superpower allies, even minor ones, could influence the larger conflict. As Niu Jun $(2010,226)$ writes in The Cambridge History of the Cold War, "both the Nationalists [on Taiwan] and the CCP [Chinese Communist Party] saw opportunities to take advantage of the contradictions and tensions that became increasingly evident as the superpowers pursued their overall goals." Chiang Kai-shek had stationed huge numbers of troops on Jinmen, profoundly affecting the lives of civilian residents, in large part so as to make the island essential to the defense of Taiwan and therefore bring it under the American security umbrella. The unexpected consequence was that in 1958 the United States felt it had no choice but to respond to the artillery attack, even at one point considering the use of nuclear weapons against China. This was a clear case of the tail wagging the dog. As one participant in the Association for Asian Studies forum put it, paraphrasing the Indian fable of the world atop a series of turtles, the Cold War in Asia is "just tails all the way down."

Two years later, the trajectory of militarization changed course. The ROC government announced that Jinmen was to become a "Model County for the Three Principles of the People," the ideological formulation developed by Sun Yat-sen that had become the ostensible basis for Guomindang rule on Taiwan. This involved a shift toward civilian infrastructure, construction, and modernization. New roads, schools, and power stations improved the material conditions of civilian life; popular mobilization through propaganda, public covenants, and compulsory discussions (as well as quotas for the collection of rats' tails) affected residents' social and cultural life. ROC planners were explicit about the motivation behind the shift: "our free and democratic political construction will strike a death blow to the bandit clique's [i.e., the CCP] People's Communes" (Jinmen xianzhii $1992,2: 559)$. For the cause of the shift was not a sudden increase in concern on the part of policymakers for the well-being of the people of Jinmen. Rather, it was the failure of the Great Leap Forward on the mainland. Though the extent of the disaster would not be known for decades, Mao's attempt to build a Chinese road to socialism, overtake the economies of the developed world, and challenge Soviet revisionism obviously had to be met with a response. The Three Principles of the People campaign was intended to show the world that the socialist road was leading the people of the mainland astray.

The patterns of geopoliticization shifted again in the 1970s, with a renewed emphasis on military preparedness. This is perhaps best captured by the construction of Jinmen's "Granite Hospital," a massive underground facility excavated from solid rock, and reportedly able to withstand a direct nuclear attack. By the late 1970s, when the hospital first opened, the CCP had already begun to experiment with the policies of opening up and reform, in part to regain the Party's popular legitimacy in the aftermath of the Great Leap Forward and the Cultural Revolution. Xiamen would soon become one of the first Special Economic Zones. I am not privy to the secret discussions of the CCP leadership, but it seems safe to assume that there was no real threat that the CCP would launch a nuclear attack on an island just a few miles from Xiamen. Nor is it unreasonable to assume that the ROC leadership was well aware of this. So why build the Granite Hospital? The answer is that its core purpose, like that of the tunnel networks constructed under several Jinmen villages, was not to defend against possible mainland attack. Rather, it was a symbol intended to warn the people of Taiwan and its superpower ally of the continued need for vigilance against the perfidious communist foe. Domestically, the key issue was rising dissatisfaction with Guomindang authoritarianism; 
internationally, the need to solidify US support even as the US established diplomatic ties with the PRC. With the construction of the Granite Hospital, all the activities of a medical facility-pediatrics, diagnostics, and surgery—were militarized and, more precisely, geopoliticized. Shifting patterns of global geopolitics were part of the experience of everyday life.

For reasons of space, I do not discuss here another aspect of geopoliticization, which is how the Cold War became a frame through which the people of Jinmen understood their own experiences. For the people of Jinmen, the Cold War was seen at the time and is remembered today less as an ideological confrontation and more in terms of the minutiae of struggles of daily life-how they negotiated curfews, blackouts, and population registration rules; how illiterate farmers learned new agricultural techniques to produce goods that could be sold to soldiers; how families responded to the commodification of sexuality and the danger of rape that seem universal wherever male soldiers gather. Their own recollections of such matters - or at least those they choose to share with an oral historian-put them at the center of global geopolitics, their everyday lives shaped by decisions made by political leaders and military strategists in far-off capitals and their actions in turn shaping those decisions. ${ }^{4}$

The interaction of global and local could lead to some extraordinary parallels and links. I have already hinted at one-despite their apparent ideological opposition, regimes on both sides of the Taiwan Strait not only were very concerned about the question of civilian hygiene, but even used very similar techniques - the eradication of ratsto mobilize and to monitor progress on this front. Major and Mitter (2003) have explored this issue of "mirror-imaging" in other contexts.

Equally interesting are the strange flows of ideas created by the Cold War alliance system. To give just one example, in the early 1970s, as part of the efforts to construct Jinmen as a propaganda symbol for both domestic and international consumption, a campaign was launched to transform Jinmen's villages into "Combat Villages." Tunnels, traps, escape routes, and firing holes were built in every combat village. Even children and the elderly, previously exempt from militia service, were now mobilized to perform specialized tasks in the event of an invasion.

According to official documents, the inspiration for the Combat Village program was the Ap Doi Moi, or New Life Hamlet, a rural pacification project in the Republic of Vietnam. ROC military officials learned about the project while participating in their country's Military Assistance and Advisory Group to Vietnam, which had been operating since 1964. Based on this explanation, one could reach the unsurprising conclusion that the lives of ordinary people on Jinmen were deeply affected as a result of the Cold War alliance system, which encouraged the non-superpower members of the alliance to support one another in order to convey the message that the alliance was more than simply a set of bilateral relationships between the superpower and its clients.

But the real story of the linkages behind the Combat Village program is more interesting still. Looking carefully at the content of the program, especially its objective of "production above-ground; life below-ground," suggests that its real inspiration was not the Republic of Vietnam's New Life Hamlet, but the tunnel warfare tactics of the

${ }^{4}$ I explore this issue in Szonyi (2008, chap. 13), and in Song (2009, 51-69). 
Republic of Vietnam's sworn enemy, the National Liberation Front (the Viet Cong). The Viet Cong in turn received guidance from Hanoi, which in turn received military advice from the People's Republic of China. The claim of inspiration by the Ap Doi Moi program was political cover for the officers involved, who were no doubt wary of being accused of being pro-communist. So in the strange geography of the Cold War in Asia, guerrilla warfare techniques refined by the PLA in the fight against Japan traveled to North Vietnam, then to South Vietnam, then to Taiwan, and then to a small island in the Taiwan Strait, where they would ostensibly be redeployed against the PLA.

While I welcome the effort to situate the Cold War in Asia in relation to larger historical processes, Jinmen and Taiwan confound the notion that the real story of the era was decolonization and the shift to informal empire. In some senses, the transfer of control over Taiwan from Japan to the Republic of China was a process of one form of colonialism being replaced by another-or at least so thought the residents of Taiwan who painted graffiti on the walls complaining "the dogs go; the pigs arrive" (Kerr 1965, 97). ${ }^{5}$ It was not until democratization, itself driven in part by broader geopolitical imperatives, that this latter form of colonialism faded away.

The Cold War was also profoundly implicated in the struggle to identify and attain modernity in Asia. Each of the superpowers had its own ideology regarding this endeavor, and sought through means fair and foul to steer the course of change in Asian societies in support of their own understanding. These efforts had profoundly disruptive, transformative, and thoroughly unexpected consequences for the peoples and societies of Asia. This is perhaps the strongest argument in favor of keeping the Cold War in Asia as a framing mechanism, because the intricacies of the superpower relationship and its impact in Europe did shape the strategies and passions with which the superpowers sought to direct change. Cold War interventionism was a distinctive form of interventionism, and it was open to distinctive forms of appropriation and manipulation.

The Cold War was at one level a struggle over mass utopias, that is, of competing ideological visions of how society should be organized. But as Greg Grandin $(2004,17)$ has written of the conflict in Latin America, "what gave that struggle its transcendental force was the politicization and internationalization of everyday life and familiar encounters" (see also Buck-Morss 2000, 3). This internationalization, or geopoliticization, was particularly central to the lives of people on and around military bases, but it was also a more widely dispersed phenomenon. Our task as historians of Asia needs to be more than just uncovering the "real story" of bipolar tension. It is to explore how the Cold War was experienced by the peoples of Asia, how it is remembered and lives on in contemporary politics and in society, and how attention to these concerns sheds light on the very nature of the relationship between the local and the global in the twentieth century.

\section{List of References}

Buck-Morss, Susan. 2000. Dreamworld and Catastrophe: The Passing of Mass Utopia in East and West. Cambridge, Mass.: MIT Press.

${ }^{5}$ Japan is an even clearer exception — the end of World War II did indeed index a moment of decolonization for Japan, but not in the usual sense of the word. 
Enloe, Cynthia. 2000. Maneuvers: The International Politics of Militarizing Women's Lives. Berkeley: University of California Press.

Grandin, Greg. 2004. The Last Colonial Massacre: Latin America in the Cold War. Chicago: University of Chicago Press.

Guofangbu and Jinmen XianzhengFu, eds. 1985. Jinmen tongji nianbiao [Jinmen statistical yearbook]. Vol. 32. Jincheng: Jinmen xianzhengfu.

JiNMEN XIANZHI [JiNMEN COUNTY ANNALS]. 1992. Jincheng: Jinmen xianzhengfu.

Kerr, George. 1965. Formosa Betrayed. Boston: Houghton Mifflin.

Kwon, Heonik. 2010. The Other Cold War. New York: Columbia University Press.

Lutz, Catherine. 2001. Homefront: A Military City and the American Twentieth Century. Boston: Beacon Press.

Major, Patrick, and Rana Mitter. 2003. "East Is East and West Is West? Towards a Comparative Socio-Cultural History of the Cold War." Cold War History 4(1):1-22.

Niu Jun. 2010. "The Birth of the People's Republic of China and the Road to the Korean War." In The Cambridge History of the Cold War, eds. Melvyn P. Leffler and Odd Arne Westad, 1:221-43. Cambridge: Cambridge University Press.

Song Yiming [Michael Szonyi]. 2009. “Zhanhuo xia de jiyi zhengzhi: Jinmen, 1949-2008” [The politics of memory under fire: Jinmen, 1949-2008]. Translated by Li Renyuan. Kaogu renleixue kan 71:47-70.

Szonyi, Michael. 2008. Cold War Island: Quemoy on the Front Line. Cambridge: Cambridge University Press.

2011. "Militarization and Jinmen (Quemoy) Society, 1949-92." In Beyond Suffering: Recounting War in Modern China, eds. James Flath and Norman Smith, 80-103. Vancouver: UBC Press.

. 2013. "Shifting Frontiers: Cross-Strait Relations in the Context of Local Society." In Mobile Horizons: Dynamics across the Taiwan Strait, ed. Wen-hsin Yeh, 74-98. Berkeley: Institute of East Asian Studies, University of California.

TANaka, Yuki. 2002. Japan's Comfort Women: Sexual Slavery and Prostitution during World War II and the US Occupation. London: Routledge. 